\title{
The Effects of Cultural Revolution of 1963 on Human Rights and Education Perspectives
}

\author{
Esmeralda Xheraj \\ University "Aleksander Moisiu" Durres, Albania. \\ E-mail: alda.xheraj@hotmail.com \\ Denis Celcima Fejzaj \\ University "Aleksander Moisiu" Durres, Albania. \\ E-mail: den_english@yahoo.it
}

Doi:10.5901/ajis.2012.v2n4p269

\begin{abstract}
:
The cultural revolution of 1963 claimed to bring new prospects in the development in albanian culture and its educational system, pretending to create the new and novative man of comunism who was in contradition to his own nature or was the project of human insticts of materialism. This man was as a slave of his freedom and had no right to think ,to feel or talk. On 6th February of 1967 Enver Hoxha's speech was concepted in only two words(To put on fire our archaic customs )...and this is the beginning of the called cultural revolution negating so the basic human rights. This revolution consisted the war against different religions and encouraged the atheism as the main principe of Marxism ideology. Albania was declared as atheist in 1976 and was the first and unique state to do so .The religion was seen as an obstacle to women emancipation and education of Albanian youth .This emancipation was thought to be done according to Marxism ideology. This war was considered even an anti-class one.This atheist regime was complying the biggest crime ever known in history...the extinction of the deepest human feeling of faithfulness turning Albanians into material beings. They were allowed to enter only into a profane world because what was sacred was as an opium to people. The duty of school was to educate the atheism to new generation .During this period the youth was taught in anti-religion spirit and dominant values of life were required on materialism science. The revolution spirit tend to inspire the youth and school was seen as the perfect place in achieving this ambition of regime. The youth strength was used as the source of the fight against religion especially linked with woman emancipation.
\end{abstract}

Key words: cultural revolution, woman emancipation, materialism education, anti-religion movement.

\section{Introduction}

A revolution is called the radical change of concepts values and norms of a society. Everything changes due to social conditions even though the changing of concepts is considered the hardest one. Each society has lived and undergone the Cultural Revolution. This kind of revolution happened through 1960 in Europe and USA. During these years the world seemed to undergo radical transformations. There were different protests in America against the Vietnam War, students' movement in 1968 in France, Britain, Germany, Poland, Spain, Czech Republic and USA. There were also the first sign of feminist and environment movements things which would form the politics of 1970-s. The mass entering of women as a powerful working class and the broadening of a lot of protests of intellectuals created new opportunities for conflict and the possibility to the forming of new class stratification. A lot of factors included in this conflict were linked mainly with class conflict as the time and concepts kept changing. During that time in the world was also talked about Revolution, freedom rock democracy human right defense and equality. The inspiration and the motive of these cultural revolutions which made the time of the European countries and the USA was only directed to democracy, 
without negating any single human right. Despite all these, our country and our state politics were inspired by Chinese revolution, judging it as the best way to the creation of the new revolutionary man. Claiming that Ex Yugoslavia and Russia were turned as revisionist, the relationships with these states were broken and all of this was done in order to justify the Chinese direction, an insensitive one either in population or in location .As always, the goal reaching justify the mean .According to Chinese theory the cultural revolution was the second phase or a new one of the socialist revolution.

\subsection{Statement of the problem}

The Cultural Revolution was thought to bring a lot of prosperity in our country. The improvements were expected to be also done on education. But the problem stands if there was a real need of negating the human rights and get centered the ideology man.

\subsection{Research Questions}

The following research questions were formulated to guide the study:

1. Does the emancipation mean the negating of religious beliefs?

2. To what extent does the collective effect of the mass revolutionized influenced the education?

\subsection{Hypotheses}

The research questions were converted to the following hypotheses:

1. The Cultural Revolution do not significantly brought progress on education.

2. The violation of the right to believe freely brought a false ideology in youth education.

\subsection{Facts analyzing}

The cultural revolution of 1963 claimed to bring new prospect in the developing of Albanian culture and its social and educational system, pretending to create the new innovative man of Communism, a man who was in contradict with his own nature and was the project of human instincts of materialism. This man was as a slave of his freedom and has no right to feel free to thinking and speaking .According to the Law $\mathrm{nr}$ 3697of 11.06.1963 for the approval of the reorganization of the educational system in Popular Republic of Albania: our educational system aims to educate and prepare the new generation to take part intensely in the construction of socialist society. Its main duty is to equip them only with scientific knowledge, to form the Marxist-Leninist points of view, to educate the youth with the spirit of socialism and proletarian internationalism. On 6 February 1967 Enver Hoxha's speech consisted in only two words .Let's burn into fire all the old and archaic customs. This was the beginning of all the "Cultural War" which had been preparing since some previous years before, deceiving people in order to get their beliefs weaker and weaker .In the same insane, year of 1967, according to $\mathrm{nr} 4337$ decree is ordered that any relation between the church and state must be cancelled. Paradoxically, Albania became the very first atheist state in the world ,negating so the constitute and its guarantee for the protection of the main human right "the freedom to believe".

The new man filled with Marxist Leninist ideology was inspired by a false achievement and ideals .Everything was under total dictate and the party was above all. The political trend was a real craze. "All are our enemies". This false consciousness and false war brought a lot of damages to our country. Such isolation cost us a lot and there is still a price to pay. All the 60-ies, all this decade shows the "Machiavellism" of the dictator not to give up the throne, just to keep it isolated in order to suppress people "knife to the bones". All of this situation led to the creation of the new and famous constitute of 1967 which proclaimed articles 37 and 55 where the state doesn't recognize any form of religion. It widely and openly prohibits the religious activity of any kind encouraging so the atheism as a Marxist principle.According to 37 Article: the state recognizes none 
of the religions, only atheism propaganda is valuable in order to create among the people the scientific and materialistic concept. If we have a look back through our history of $X X$ century we will find out that all this atheism was pretended to be inspired since the creation of Albanian myth: Being Albanian is our only religion .The origin of this saying stands in one of our most famous writers of Renaissance, Vaso Pasha and it was written in the end of XX century, the time when the Albanian elite started the nationalist movement. This powerful expression became the base of Albanian nationalism and the heart of our war to protect Albanian borders. But this was misinterpreted the same as Nietzsche's revolutionary philosophy, calling him the Hitlerian philosopher .With the communism rule this essentialist approach was related with Marxism theory just to show and to enforce the idea that we had no faith at all The religion represents a really useless institution and is a huge obstacle for the logical and critical thinking of the new generation. Our educational system aims to educate and prepare the new generation to take part intensely in the construction of socialist society. Its main duty is to equip them only with scientific knowledge, to form the Marxist-Leninist points of view, to educate the youth with the spirit of socialism and proletarian internationalism. Educating and evolving the new man ideologically rather than intellectually the high school and university students got an active part in the demolishing of churches and mosques .An outstanding examples gave the youth of Durres City who was followed next by the youth of all country. The new generation in general and scholars were less affected by religion. During this period there were closed 2035 churches and mosques and 214 clerics were imprisoned and many of them were executed. Among them, there was an outstanding character in education, in spite of being a cleric, Hafiz Ibrahim Dalliu. According to the number 4263 decree of 11/04/1967 all the wealth that churches and mosques owned were considered as a state property

In 1967 by the youth of "Naim Frasheri" school in Durres started a new era of the radical changes to fight the anti revolutionary behavior. This meaningless initiative of the communist youth was followed by the students of "29 Nentori" school and later by all the working class of Durres city. In a letter directed to the government the youth organization of "Naim Frasheri" school was required.

Now is the high time that all the clerics earn the living by themselves and not by frustrating poor people's work.

In the relation of 1963, complied by Ramiz Alia, Nexhmije Hoxha and Fadil Peçrani, was written:

"The school has the duty to educate our children to be atheist. Through the learning and teaching process through the educative work of teachers and youth organizations there should be a lot of work done that the new generation feel free of religious prejudices. The peasant, the woman and the elderly people is hard to convince that there is no God. But with pupils and students, this must be reached without conditions."

The socialist revolution is a process which doesn't end, either with the getting of power or the construction of socialism. All this is a deepening and developing process in every part of society." The Man is the most precious capital", this new man educated with anti technocratic anti-intellectualist and atheist spirit.

The youth of that period was educated based on the aspect mentioned and the values of life should be found in the materialistic science, adopting them as the only constant values of our ideological understanding .The revolutionary spirit was spread everywhere and the ideological fight was applied on any form of the traditional and archaic society.

The aims of revolution were to revolutionarize people's consciousness with the new ideology of working class and to purify our superstructure from any bit of old rubbish .As Engels mentioned: "...to defend , protect and consolidate its victory, the working class not only should demolish the old bourgeois regime but also to protect and ensure itself even by the deputies and its own intellectuals, taking the right precautions that the state ,its institutions and people not to become and behave as their masters."All this led to the necessity of ideological form of education, because the religion, technocratism and intellectualism opened the way to the degeneration of some socialist countries. Basing upon all the decision of the party there were applied three main components in the high school and university: Teaching and learning professional practices, productive work, physical and military education. The indoctrination of the school subjects brought to the destruction of 
pedagogical and scientific character, the qualification and the specialization of the teaching staff, reaching too far even to the closure of schools which tended to be European oriented.

\subsection{Conclusion}

The revolution brings progress in a country. It may seem as a big paradox to overlook this socialist revolution and find the real progress in it.

To be honest the only good of all this ideological war and fight was only the anti-analphabetism one but this immense right for education had the maximum price of sacrificing another fundamental human right, the right to believe freely.

The new man filled with Marxist-Leninist ideology was inspired by false achievements and ideals. Everything was under the dictate of Marxist- Leninism and the party was above all the politics trend was a real.

According to the historian Todeusz Czekolski, "Only by arriving to the heart of a society we could have a clear idea about its political system". Even though the communism in Albania war a part of Eastern Europe it should be viewed apart. The consequences of revolution an education brought the ideologically educated youth by letting aside and accustoming it with the negation of basic human rights.

According to Marx:"When a class thinks a thing, the thing it thinks is not the thing it thinks it thinks, but it is instead a false consciousness, an ideology."

And to finish this all, Marxism ideology was a perfectly misinterpreted one by the party state and dark egocentric forces of the so called Cultural Revolution.

\section{References}

The constitution of 1976 articles 37/55.

Enver Hoxha speech on 6th February 1967 Albanian legislation.

Presidium decrets no 42/63 of 1967.

"Zeri I popullit Journal"

At Gjergj Fishta "Works"

Dilaver Sadikaj .Historical studies. (Nr. four 1981)

"The movement against the religion in years 60 's"

"Antireligious propaganda written on communist press.(1945-1966)"

The development of Islamic culture of Albanians xx century.

The Martyrdom of Catholic Church.

Pedagogy, By Prof. Dr Musa Kraja

The history of education in Albania

Albanian diplomacy of 60's reference by direct of defense and security

Volume five. The development of five congress 